\title{
МОВНА ГРА В АНГЛО-УКРАЇНСЬКОМУ ХУДОЖНЬОМУ ПЕРЕКЛАДІ
}

\author{
ТЕТЯНА ОЛІЙНИК \\ Тернопільський національний педагогічний \\ університет ім. Володимира Гнатюка, Тернопіль - Україна \\ GRA SŁÓW W ANGIELSKO-UKRAIŃSKIM \\ TŁUMACZENIU ARTYSTYCZNYM \\ TETIANA OLIJNYK \\ Tarnopolski Narodowy Uniwersytet Pedagogiczny im. W. Hnatiuka, \\ Tarnopol - Ukraina
}

STRESZCZENIE. W artykule rozpatrywana jest gra słów w angielsko-ukraińskim thumaczeniu artystycznym, szczególnie rozpowszechniona w codziennej komunikacji werbalnej. Istnieją strukturalne i niestrukturalne rodzaje gry słów. Tylko jeden rodzaj odchyleń może być stosowany w grze słów jednocześnie. Udowodniono, że efekt komiczny jest najbardziej oczywistą cechą gry słów. W artykule zaproponowano klasyfikację gry słów zgodnie z intencją mówcy.

\section{LANGUGE PLAY IN ENGLISH-UKRAINIAN FICTION TRANSLATION}

\section{TETYANA OLIYNYK}

Volodymyr Hnatyuk Ternopil National Pedagogic University, Ternopil — Ukraine

ABSTRACT. The article deals with language play in English-Ukrainian translation. It is very popular in every-day verbal communication. There are structural and non-structural types of language play. Only one type of deviation can be used in language play at a time. It is proved that comic effect is the most evident feature of language play. The classification of language play according to the speaker's intent and the classification of language play devices are suggested in the article.

$\Gamma$

Тра зі словом є універсальною діяльністю людини. Ми одержуємо задоволення, розбиваючи слова на частини, реконструюючи їх у новому звучанні, знаходячи приховані в них смисли й намагаючись оперувати ними за спеціально винайденими правилами. Словесні головоломки, перепалки, змагання можна зустріти повсюди: в газетах, журналах, у школах, університетах, на радіо й телебаченні, на вечірках, у різноманітних індивідуальних контекстах (кросворди, анекдоти, обговорення в соціальних мережах тощо).

Усі ми беремо участь у грі зі словом, принаймні, реагуємо на неї. Сьогодні спостерігаємо гру слів набагато частіше, ніж будь-коли в історії людства.

Однак слід уточнити термінологію дослідження. Деякі вчені розмежовують поняття "мовна гра" й “мовленнєва гра". У цілій низці праць, присвячених цій проблемі, запропоновано теоретичне й практичне обгрунтування для їхнього розмежування. На нашу думку, ці два терміни мають право на існування. "Мовленнєва гра" передбачає, що гра реалізується в мовленні з урахуванням ситу- 
ативної специфіки й особливостей характеру співрозмовника. Досягнутий результат завжди є унікальним. Термін “мовна гра” виражає суть явища, позаяк

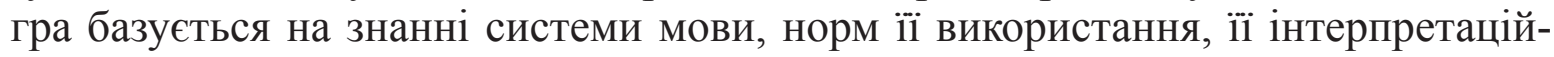
ного потенціалу. На початку 80 -х років минулого століття відомі мовознавці, зокрема О. Земська, М. Китайгородська, С. Ширяєв ${ }^{1}$, Н. Розанова ${ }^{2}$, використовували термін “мовленнєва гра". Цікаво, що в роботах відомого британського лінгвіста Д. Крістела вживаються терміни Language Play ${ }^{3}$ i Language Game ${ }^{4}$ (дослівно “мовна гра”), що дає можливість говорити про уподобання англомовних дослідників уживати більш “системний” термін. У цьому дослідженні послуговуємося терміном "мовна гра".

Мовна гра - це вид гри, в якій мова є головним об’єктом уваги. Оскільки вербальне спілкування — невід'ємна частина соціальної взаємодії, мовна гра - явище соціальне. Ті учасники комунікативного акту, які володіють умінням мовної гри, користуються успіхом і можуть досягти престижного суспільного статусу. Мовні маніпуляції як складники соціальної взаємодії відбуваються в межах гри. Мета участі в такій грі - розваги, забава, естетичне задоволення, в ній задіяні як діти, так і дорослі.

Мовну гру поділяємо на структуровану й неструктуровану. У межах системи гри налічують багато різновидів. Ця кількість необмежена через те, що мова в мовній грі використовується нестандартно, з порушенням загальних мовних та естетичних норм. Насправді, до гри залучаються всі структурні елементи й рівні мови, наприклад, терміном “скоромовки” позначають мовну гру, що базується на труднощах вимови, коли речення складається із подібних звукових комплексів і важливою умовою при цьому є швидкість вимови, порівн.: речення She sells sea shells on the sea shore; The shells that she sells are sea shells I am sure; Betty Botter bought some butter, But she said "The butter's bitter, And a bit of better butter Will make my butter better" є скоромовками, оскільки в них чергуються артикуляційно близькі звуки, що містяться в суміжних позиціях. Приклади українською мовою: А дідусь Опанас Нам купив ананас, Тож приходьте до нас - Почастуємо вас; Пиляв Пилип поліна з лип. Притупив пилку Пилип; Мила митися не вміла. Мила мило з рук не змила.

Віртуозне виконання передбачає швидке багаторазове повторення речення. Якщо помилки у вимові призводять до втрати змісту, фраза починає звучати не зовсім пристойно, то гра викликає ще більше позитивних емоцій.

Інший тип мовної гри побудований на створенні фраз-паліндромів, що зберігають смисл (звучать однаково) у зворотному напрямку: I щзо сало? Ласощі ...; Паліндром - i ні морд, ні лап. Паліндром може мати навіть форму вірша. Кожен рядок вірша є окремим паліндромом:

Козак з казок.

Уже лисі ліси... Лежу.

Уже ребра татар бережу.

Умру. Суму сум - у сурму,

А мене нема... 5 .

${ }^{1}$ Е. Земская, М. Китайгородская, Е. Ширяев, Русская разговорная речь. Общзие вопросы. Словообразование. Синтаксис, Москва 1981.

${ }^{2}$ М. Китайгородская, Н. Розанова, Языковое существование современного горожанина: на материале языка Москвы, Москва 2010.

${ }^{3}$ D. Crystal, The Cambridge Encyclopedia of Language. Second edition, Cambridge University Press 1997, pp. 59, 64-65.

${ }^{4}$ Ibidem, PР. 265, 395-399.

${ }^{5}$ О. Будзей, 3 архіву душі, Київ 1999. 
Весь вірш є одним суцільним паліндромом (вірш-паліндромон):

І трава, ніч...

О-охи та ахи...

Луджені зорі,

Аромат лексидій,

Юль фото...

Флюїди скель,

та моря,

і роз...

... I не жду лиха,

A - тихо очі на варті... ${ }^{6}$.

Приклади паліндромів англійською мовою: dad, Anna, refer, sees, nun, deified; фрази: I moam, Naomi; So patient a doctor to doctor a patient so. Така структурна гра заснована на специфічних фонологічних обмеженнях мови.

За допомогою зміни фонологічної структури слів і речень (складання, поділ, перестановка, заміна) створюються різноманітні таємні ігрові мови. Однією з найпопулярніших ігрових мов в англомовних країнах є так звана Pig Latin. Слова в цій “мові” створюються за допомогою фонологічних трансформацій: перестановки першої фонеми кожного слова на кінець з використанням з'єднувальної комбінації голосних звуків ау [ei]. Напр., англійське речення She likes to sing буде мати форму: Hesay ikeslay otay ingsay. Нові слова не мають значення, однак утворюють абсурдні набори звуків для вживання нісенітниць 3 ігровою метою для підняття настрою.

У відомому американському фільмі “The Nell” головна героїня використовувала таку таємну мову для спілкування зі своєю сестрою-близнючкою, а потім вона почала її використовувати й для спілкування з довкіллям. Такі таємні ігрові мови описані та проаналізовані в багатьох мовах і культурах (див.: Жирмунський ${ }^{7}$, Sherzer $^{8}$, Белл ${ }^{9}$ ).

Активно використовуються в мовній грі й каламбури. Це один із найпоширеніших засобів створення суб'єктивно-комічного ефекту. Каламбур (франц. calembour - гра слів) - стилістична фігура, створена на основі використання омонімів, омографів, повторів слів та їхніх комбінацій і модифікацій із подібним звучанням та багатозначністю. За допомогою каламбуру автор здебільшого досягає жартівливого, комічного ефекту. Використовується каламбур для урізноманітнення й збагачення стилю в художній літературі, ораторському мистецтві, журналістиці ${ }^{10}$. Походження слова пов'язують 3 італійським висловом calamo burlare "жартувати за допомогою пера", або з назвою міста Калемберг, де мешкав пастор Вейганд, який славився жартами. Засобами створення каламбуру є полісемія слів і сполук; омонімія різних типів, подібність слів і сполук за звучанням (парономазія); псевдосигонімія, псевдоантонімія; поєднання синтаксичних псевдодериватів. Дослідники називають однією із ознак каламбуру різке оцінне протиставлення елементів, що обігруються, причому першу позицію обіймає позитивно оцінюваний компонент, а другу — негативний ${ }^{11}$.

${ }^{6}$ К. Павляк, Алушта, Тернопіль 2010.

${ }^{7}$ В. М. Жирмунский, Национальный язык и соииальные диалекты, Ленинград 1936.

${ }^{8} \mathrm{~J}$. Sherzer, An areal-typological study of American Indian languages north of Mexico, Amsterdam, Oxford 1976.

${ }^{9}$ Р. Белл, Социолингвистика: цеели, методы и проблемы, пер. с англ., Москва 1980.

${ }^{10}$ Словник тропів і стилістичних фігур, авт.-укл. В. Ф. С в ятов вець Київ 2011, с. 90.

${ }^{11}$ О. Селів ванова, Лінгвістична енциклопедія, Полтава 2011, с. 219. 
У комедіях В. Шекспіра каламбур часто заснований на конверсії, розчленуванні слів і фразеологічних зворотів. Для каламбурів використані прізвища персонажів, назви літер алфавіту тощо.

У комедіях Марні зусилля кохання, Віндзорські жартівнииі та Багато галасу з нічого нараховуємо близько 400 прикладів каламбуру. Це найскладніший прийом створення комічного ефекту в тексті перекладу. Частка переданого каламбуру приблизно становить 30 \%. У комедії Марні зусилля кохання один із найпростіших каламбурів базується на омонімах — іменникові base (“низ”) і однозвучному прикметникові base (“негідний, підлий”):

Armado. I do affect the very ground, where he shoe, which is baser, ...doth tread (Act 1, Scene 2).

Армадо. Я люблю навіть грунт (хоч це низький предмет), що топче ії черевик, предмет ще нижчий, бо його спрямовує ії нога, що $є$ вже зовсім низьким предметом (Дія 1, Сцена 2).

Гру слів зазвичай дуже важко передати. Вона є тим засобом, у процесі відтворення якого найчастіше трапляються втрати в перекладі. Наведемо приклад такої втрати:

Moth. ... Signior Costard, adieu.

Costard. My sweet ounce of man's flesh, my incony Jew! (Act 3, Scene 1). У цьому прикладі гра побудована на співзвучності слів "adieu”i “Jew"'2.

Перекладачеві не вдалося передати іiі:

Метелик. ....Прощай, Довбешко-пане!

Довбешка. Солодкий він шматок! Лукавство незрівнянне! (Дія 3 , Сцена 1$)^{13}$.

На яскравий каламбур натрапляємо в трагедії В. Шекспіра Гамлет у перекладі Л. Гребінки:

Клянусь, я за красу не дбаю, пані,

Що збожеволів він, на жсаль, ие правда;

І правда, що на жсаль; і жаль, що правда;

Зворот незграбний, ну, та Бог із ним.

Я обійдусь без правил красномовства.

Відомо нам, щзо збожеволів він;

Тепер знайдім причину ицього чину.

Знайдімо себто чин його причини,

Чи пак яким же чином він спричинивсь ${ }^{14}$.

Каламбур часто є основою приказок і прислів 'їв: A friend in need is a friend indeed; East or West, home is best; Forewarned is forearmed. В українській мові: Ти йому про Тараса, а він тобі - півтораста; Полюбила Маруся та любого Петруся, та що скаже матуся; Сякий такий Пантелій, а все-таки - веселій. Каламбур властивий скоромовкам: Peter Piper picked a peck of pickled pepper, A peck of pickled pepper Peter Piper picked; If Peter Piper picked a peck of pickled pepper. Where's a peck of pickled pepper Peter Piper picked? Don't trouble trouble; Till trouble troubles you.

В українській мові: Летів горобець через безверхий хлівець та вхопив гороху без червотоку, без червоточини, без прачервоточини та й пурх - полетів; Правда, щео ми ходили дещо і гуторили про що, тільки коли я хоч що або абощо, то нехай мені казна-що - от що, а не то щэо! А ви ще кажете, щоб я там що-що або абощо; Був собі цебер - перецебрився, мав діти цебренята - перецебренята.

${ }^{12}$ W. Shakespeare, The great comedies and tragedies, London 1999.

${ }^{13}$ В. Шекспір, Твори в 6 т., Київ 1985, т. 4, с. 215.

${ }^{14}$ Там само, с. 78. 
У художньому тексті зазвичай присутня багатозначність. Використання стилістичних тропів (метафори, алегорії, іронії тощо) сприяє виникненню декількох інтерпретацій у межах одного контексту. Неоднозначність висловлювань уважається невід'ємною частиною художньої мови та ïі інтерпретації.

Каламбур вибудовується на невідповідності форми і значення. Слово чи фраза вживаються так, що пряме значення породжує вторинне метафоричне значення. Більшість дитячих загадок мають цю рису: Who crosses the river twice and is still not clean? - A dirty double-crosser.

Зазначимо, що в мовній грі одночасно може вживатися лише один вид девіації. Якщо ми задіюємо фонологічну систему, граматика й лексика повинні залишатися стабільними; змінюючи граматичні чи лексичні структури, не варто торкатися вимови. Це дуже важливо, позаяк мова втратить здатність передавати інформацію й сама ідея гри буде втрачена ${ }^{15}$.

Уважається, що ми граємо з формами мови для підсилення виразності чи для створення комічного ефекту. Комічний ефект $є$ найочевиднішим виявом мовної гри. Відомо багато визначень комічного. В. Пропп ${ }^{16}$, напр., пов'язує поняття комічного $з$ відхиленням від норми. М. Бахтін ${ }^{17}$ і його послідовники стверджують, що комічне - це таке відхилення від норми, що відповідає двом умовам: 1) призводить до виникнення двох змістових планів; 2) ні для кого в певний момент не $є$ небезпечним. Певний вид мовної гри, метою якої $є$ створення комічного ефекту, називається мовним жартом. В. Санніков ${ }^{18}$ визначає мовний жарт як мовну неточність, зумисне допущену мовцем. Мовна гра за своєю суттю зазвичай звеличує свій об'єкт, а мовний жарт, навпаки, - дискредитує.

Зауважимо, що не кожний жарт, що словесно виражений, $є$ мовним. Дослідники розрізняють жарт предметний і власне мовний. Т. Грідіна ${ }^{19}$ зазначає, що в мовному жарті мовна форма не порушується, синонімічні заміни не допустимі, i, як правило, жарт не передається засобами іноземної мови. Д. Крістел ${ }^{20}$ також уважає, що мовна гра в комічних творах рідко долає національні кордони.

Мовний жарт є важливим виявом мовної гри, метою якої є не тільки розвага. За допомогою жарту можна завуалювати повідомлення й виразити приховані наміри, по-новому передати думки, затаїти невігластво. Іноді навіть можлива заміна понять, позаяк мовний жарт виконує переважну більшість функцій мовної гри.

Узявши за основу функції мовного жарту, пропонуємо класифікацію мовної гри за намірами:

1. Гра-іронія (з метою дискредитації зображуваного): а) гра-сатира (негативне ставлення до об’єкта); б) гра-гумор (дружнє ставлення до предмета повідомлення). 2. Мовотворча гра (пошук найбільш яскравих способів виразити думку, заповнення лакун у системі мови). 3. Гра як лінгвістичний експеримент (пошук значень мовної одиниці, перевірка мовної здатності особистості, індивідуальних уявлень про мову тощо). 4. Гра як засіб розваги й самоствердження.

${ }^{15}$ D. Crystal, Language Games, Harmondsworth, England 1980.

${ }^{16}$ В. Я. Пропп, Проблемы комизма и смеха, Санкт-Петербург 1997.

${ }^{17} \mathrm{M}$. Бахтин, Проблема текста в лингвистике, филологии и других гуманитарных науках. Опьтт философского анализа, Москва 1979.

${ }_{18}$ В. 3. Санников, Русский язык в зеркале языковой игры, Москва 1999, с. 26.

${ }^{19}$ T. А. Гридина, Языковая игра: стереотип и творчество, Екатеринбург 1996, с. 30-31

${ }^{20}$ D. Crysta1, Ibidem, p. 116. 
В. Санніков ${ }^{21}$ подає класифікацію мовної гри, взявши за основу багаторівневий характер мови. Він розглядає випадки мовної гри у фонетиці, морфології, синтаксисі тощо. Дослідник стверджує, що кожний граматичний засіб, фонологічний принцип може бути використаний як механізм здійснення мовної гри.

У розмові мовна гра виступає як засіб комічного. Ї̈̈ вживають для того, щоб викликати посмішку, сміх, створити гарний настрій чи іронічне ставлення до повідомлення. Однак, окрім комічної функції, така гра виконує ще й емотивну (експресивну) функцію.

Прагматична реалізація мовної гри різноманітна. Її використовують для пожвавлення бесіди, точнішої передачі думки, образної й виразної репрезентації повідомлення. Створенню мовної гри слугують: 1. Перифрастичні номінації (використання метафоричних значень слів, літературних асоціацій тощо: бити чолом - to throw oneself at smb's feet; nimu з протягнутою рукою to go to smb with cap in hand). 2. Використання слів з іншим денотативним значенням для експресивності повідомлення: халупа / апартаменти (про звичайну квартиру) - hut / accommodation unit (apartment). 3. Метонімічна конкретизація й генералізація (а) зображення за конкретною дією, деталлю: Будеш густи? (пилососити) - Will you hoover? б) узагальнення, конкретизація коли звичайне явище, дія описується як соціально-значуще: Купив апаратуру? (напр., про купівлю праски) — Did you buy equipment? (an iron)). 4. Розмовні порівняння (стати червоним як телефонна будка (за червоним кольором телефонних будок y Великобританіï) - to be as red as call-box). 5. Зворотність тропів (використання метафоричних епітетів): Я як руїна - I am like a ruin. 6. Цитування (використання цитат з художніх творів, пісень, афоризмів). Цей прийом заснований на спільному культурному досвіді. Якщо він відсутній, мовцеві не вдасться досягнути бажаного стилістичного ефекту. 7. Каламбур (Розмовний каламбур виражає бажання мовця пожартувати: Він гарно грає на роялі, справжній рояліст (замість niaнicm). 8. Паронімічна атракція (каламбурно можуть уживатися повні омоніми, омоформи, пароніми). 9. Поєднання різних прийомів мовної гри (У реальному житті окремі прийоми не функціонують ізольовано. Зазвичай мовний жарт чи мовна гра породжують жарт чи гру у відповідь, залучаючи різні прийоми $)^{22}$. Наведена схема досить повно характеризує явище мовної гри. Вона, звичайно, не універсальна, оскільки взято за основу лише тропи й фігури. Якщо взяти за основу інший принцип, то й класифікація буде іншою.

Отже, мовна гра має креативний характер і заснована на творчій здатності індивіда використовувати мовні засоби. Її феномен демонструє співвідношення мовного стандарту й відхилення від нього, кореляцію нормативного й ненормативного у використанні мовних одиниць. Запрограмований ефект мовної гри - естетичний вплив на реципієнта, мета - досягнення комічного ефекту.

Мовна гра торкається усіх рівнів мови залежно від потенційної здатності мовних одиниць до різної інтерпретації, а також від лінгвокреативного, лінгвокраїнознавчого мислення індивіда. Якщо йдеться про художній текст, то слугують створенню мовної гри всі семантично значимі аспекти побудови тексту.

У процесі перекладу мовної гри необхідно враховувати національну специфіку народу-реципієнта. Питання, як уникнути у відтворенні втрат на всіх мовних рівнях, потребує подальших наукових студій.

${ }^{21}$ В. 3. Санников, указ. источник, с. 241.

${ }^{22}$ Русская разговорная речь: Фонетика, морфология, лексика, жест, отв. ред. Е. А. Земская, Москва 1983, с. 172-211. 